\title{
Digital Badges for Professional Development: Meeting the Evolving Needs of Library Personnel with the CLA School Library Standards
}

Sandra Bebbington, MIS

Project Leader: Digital Citizenship, Information Literacy and School Libraries. Quebec School Librarians Network (QSLiN). Ministère de l'Éducation-Direction des services à la communauté anglophone. Québec

sandra.bebbington@education.gouv.qc.ca

Ellen Goldfinch, MLS

Collaborator: Information Literacy and School Libraries. Quebec School Librarians Network (QSLiN). Ministère de l'Éducation-Direction des services à la communauté anglophone. Québec

ellen.goldfinch@education.gouv.gc.ca

Julian Taylor, MLIS

Collaborator: Digital Citizenship, Information Literacy and School Libraries. Quebec School Librarians Network (QSLiN). Ministère de l'Éducation-Direction des services à la communauté anglophone. Québec

julian.taylor@education.gouv.qc.ca

\begin{abstract}
The Canadian Library Association published Leading Learning, a library standards guide for school libraries in 2014. The Quebec School Librarians Network (QSLiN) adapted these standards into a digital badge professional development program. Digital badges are a means for providing online learning, assessment and credentials in an interactive and dynamic way. They allow achievers to gain new knowledge and be recognized for skills and competencies that may otherwise go unnoticed. QSLiN's digital badge program facilitates the transition of traditional school libraries into school Library Learning Commons. This badge program pilot project hopes to connect the Canadian school library community as well as provide an accessible and user-friendly form of professional development to all school library personnel regardless of their location. Research suggests that the two greatest barriers to professional development are time and money. As such, having a free online program helped to alleviate both barriers. This paper discusses the process we undertook at QSLiN to incorporate digital badges into our professional development initiatives. We will discuss the first phase of this pilot project as well as address future considerations for the program.
\end{abstract}




\section{Keywords}

Professional development, digital badges, Canadian Library Association, school libraries, school library standards

\section{Introduction}

Having innovative and up-to-date school libraries has been increasingly important, as education has evolved exponentially over the past few decades. While there is a myriad of studies that show evidence of the importance of school libraries' impact on student achievement (Lance \& Hofschire, 2012; Barak, 2012; Haycock, 2011, Oberg, 2011), remaining valuable and relevant to the school community is essential to the school library's survival. Having qualified up-to-date library personnel is an essential piece of the puzzle if we want engaging library programs and effective library spaces. According to Fields (2015), adaptation is the key to remaining relevant in this quickly evolving profession. To be able to adapt, "learning opportunities in new competencies must be made visible" (Fields, 2015, p. 1). This can be difficult in the world of education, as teaching and learning strategies are constantly changing. As school library staff, we are strategically positioned to make a difference in the school dynamic. According to Marge Cox (2015), "As school library professionals, we have the wonderful opportunity to work with the entire staff. This circumstance provides us with the chance to get to know them better than most of the other staff members do. We can help set the tone for the school." (p.48). Two of the greatest barriers to receiving professional development are time and money (Bellardo-Hahn \& Lester, 2012). Creating opportunities for professional development that are economical (or free) and flexible can potentially increase the number of participants seeking new professional learning opportunities. Online learning programs that incorporate digital badges can help fill this need.

This article looks at how the Canadian Library Association (CLA) has made the competencies for school librarianship more standardized and visible, and how a group of librarians in Quebec has made efforts to adapt these competencies into a userfriendly, free and accessible form of professional development. We will discuss the process by which QSLiN undertook to incorporate digital badges as a component of our professional development initiatives as well as our desire to see our school libraries evolve into a ubiquitous part of every school. This is the first phase of a pilot project that will allow us to assess the success of our initiative and make any necessary changes before we begin to incorporate the badges into other areas of QSLiN's professional development program.

\section{Canadian School Library Standards}

The CLA published their innovative and much anticipated guide for school libraries in May 2014. This document, titled Leading Learning, is a comprehensive guide that discusses how the school library can evolve into a dynamic Library Learning Commons (LLC). These standards have created a pathway by which school library personnel can work to improve their libraries. This publication is a godsend to anyone working in school libraries as it covers every facet of the library, for example, library design, 
collection development and literacy. It also includes a variety of resources, links, templates and examples to help library personnel improve their school library and better support the 21st century learner. See Figure 1 for an overview of the standards.

\begin{tabular}{|c|c|c|c|c|}
\hline $\begin{array}{l}\text { Facilitating } \\
\text { collaborative } \\
\text { engagement to } \\
\text { cultivate and } \\
\text { empower a } \\
\text { community of } \\
\text { learners }\end{array}$ & $\begin{array}{l}\text { Advancing } \\
\text { the learning } \\
\text { community to } \\
\text { achieve school } \\
\text { goals }\end{array}$ & $\begin{array}{l}\text { Cultivating } \\
\text { effective } \\
\text { instructional } \\
\text { design to co-plan, } \\
\text { teach and assess } \\
\text { learning }\end{array}$ & $\begin{array}{c}\text { Fostering literacies } \\
\text { to empower life- } \\
\text { long learners }\end{array}$ & $\begin{array}{l}\text { Designing learning } \\
\text { environments } \\
\text { to support } \\
\text { participatory } \\
\text { Iearning }\end{array}$ \\
\hline Vision for Learning & $\begin{array}{l}\text { Planning for School } \\
\text { Improvement }\end{array}$ & $\begin{array}{l}\text { Instructional } \\
\text { Leadership }\end{array}$ & Literacy Leadership & $\begin{array}{l}\text { Designing for a } \\
\text { Collaborative } \\
\text { Physical LLC }\end{array}$ \\
\hline $\begin{array}{l}\text { Design for } \\
\text { Collaboration }\end{array}$ & $\begin{array}{l}\text { Principal Collaborative } \\
\text { Role }\end{array}$ & $\begin{array}{l}\text { Instructional } \\
\text { Partnerships }\end{array}$ & Engaging Readers & $\begin{array}{l}\text { Designing for a } \\
\text { Collaborative } \\
\text { Virtual LLC }\end{array}$ \\
\hline $\begin{array}{l}\text { Partners in } \\
\text { Collaborative } \\
\text { Learning }\end{array}$ & $\begin{array}{l}\text { Teacher-Librarian } \\
\text { Collaborative Role }\end{array}$ & $\begin{array}{l}\text { Engaging with Inquiry } \\
\text { Approaches }\end{array}$ & Information Literacy & $\begin{array}{l}\text { Designing for } \\
\text { Accessibility in } \\
\text { the LLC }\end{array}$ \\
\hline $\begin{array}{l}\text { Student and } \\
\text { Community } \\
\text { Partnerships }\end{array}$ & $\begin{array}{l}\text { Teacher Collaborative } \\
\text { Role }\end{array}$ & Differentiated Learning & Critical Literacy & $\begin{array}{l}\text { Designing for } \\
\text { Responsive Print and } \\
\text { Digital Collections }\end{array}$ \\
\hline $\begin{array}{l}\text { School Administration } \\
\text { Partnerships }\end{array}$ & $\begin{array}{l}\text { Support Staff } \\
\text { Collaborative Role }\end{array}$ & $\begin{array}{l}\text { Technology for } \\
\text { Learning }\end{array}$ & $\begin{array}{l}\text { Digital Literacy and } \\
\text { Citizenship }\end{array}$ & $\begin{array}{l}\text { Designing for } \\
\text { Creativity and } \\
\text { Innovation }\end{array}$ \\
\hline \multirow[t]{2}{*}{$\begin{array}{l}\text { District Administration } \\
\text { and Consultant } \\
\text { Partnerships }\end{array}$} & $\begin{array}{l}\text { District Administration } \\
\text { and Consultant } \\
\text { Collaborative Role }\end{array}$ & $\begin{array}{l}\text { Assessment for, of } \\
\text { and as Learning }\end{array}$ & Cultural Literacy & $\begin{array}{l}\text { Designing for } \\
\text { Participatory } \\
\text { School Culture }\end{array}$ \\
\hline & & $\begin{array}{l}\text { Evidence-Based } \\
\text { Practice }\end{array}$ & Literacy Partners & \\
\hline
\end{tabular}

Figure 1. Canadian School Library Standards Overview (CC 2.0 BY, Canadian Library Association, 2014)

\section{English Quebec School Libraries and the Quebec School Librarians Network (QSLIN)}

Many school libraries in Quebec, as well as those in the rest of Canada, have experienced budget cuts over the past few years. Often, this has resulted in a decrease in personnel or in the number of hours they can work. Staffing ranges in the system depending on the school board: some school boards employ librarians, library 
technicians or other staff members, part time or full time, while others use volunteers to help manage the individual school libraries. It should be noted however, that since 2008, the Quebec Ministry of Education has had a librarian-hiring grant initiative for librarians to be hired at the board level. This grant has allowed school boards that would not otherwise have the funding to employ a subsidized board librarian on staff to support various initiatives from managing school library staff to implementing literacy initiatives. School libraries in Quebec range from large, recently renovated libraries to smaller spaces or even travelling carts. Quebec has nine English school boards that span the entire province, with many schools located in rural and/or isolated areas. This has added to the challenge of building a cohesive and active school library community. The wide geographic distribution of Quebec's school librarians also creates a challenge to provide professional development opportunities in person.

One means of supporting the school library community was the development of the Quebec School Librarians Network (QSLiN). QSLiN represents librarians from the nine English public school boards, as well as any English private school that wishes to participate. The Network, which includes Ministry of Education liaisons, meets every six weeks to discuss initiatives to support school libraries and their personnel in meeting the needs of the English educational community. This committee arose in particular from requests in the community to find better support for school libraries regarding information literacy and digital citizenship. Given the heavy workloads and limited hours of library personnel in our community, a discussion arose about how we could facilitate the process of encouraging our school librarians and other staff and volunteers to take on the challenges of evolving the school library into Library Learning Commons. As a committee, we wanted to find an innovative and easy way to support professional development. Subsequently at one of the meetings, the concept of an online professional development program was discussed, and from there, the idea of a digital badge program emerged.

\section{Digital Badges}

"Digital badges are an assessment and credentialing mechanism that is housed and managed online. Badges are designed to make visible and validate learning in both formal and informal settings, and hold the potential to help transform where and how learning is valued." (MacArthur Foundation). In a report by the Alliance for Excellent Education and the Mozilla Foundation (2013), digital badges are described as "credentials that represent skills, interests, and achievements earned by an individual through specific projects, programs, courses, or other activities. A credible badge stores information online through a digital hyperlink about the associated skills, as well as what projects and tasks the badge holder completed to obtain it." (p. 2)

Digital badges as a way to display one's accomplishments emerged in the mid 2000's, but remained relatively unheard of until the Mozilla Foundation and Peer 2 Peer

University published a white paper discussing the merits of digital badges. Since then, digital badges have become more pervasive and can be found as a means to display accomplishments online ranging from university courses to travel reviews such as on Tripadvisor. Digital badges offer a unique way to learn or improve new skills or 
competencies often in an interactive and dynamic way. They allow achievers to be acknowledged for a variety of skills or interests that may not be recognized in a more formal setting or are simply not job specific (Jovanovic \& Devedzic, 2014). They also present opportunities for community interaction. Digital badges contain a significant amount of metadata that allow others to see important facts such as what type of accomplishment was achieved, how it was earned and who issued the badge (Jovanovic \& Devedzic, 2014). According to the Harvard Business Review, digital badges will continue to play a significant role in the future of accreditation (Schrage, 2012). Schrage goes on to state that "the ability to measure and assess real learning and skills acquisition in virtual environments" will allow online education to excel (Schrage, 2012, para. 5).

\section{Digital Badges and QSLiN}

\section{Process}

Our working team of three started by reading and analyzing the CLA Standards and pulling out the key points and how they might be measureable. After much discussion, the main components of the badging program were established based on the key aspects of the standards. Research was then done to find a variety of content that would meet the needs of different types of learners (for example, videos, articles, infographics and images). Once the content was gathered, edited and created, it then had to be arranged in a cohesive manner and remain interesting, while not overwhelming. Once this was accomplished, the platform and badge program to be used had to be established.

\section{Infrastructure}

After researching the various digital badge platforms available, we decided to use WordPress and the Credly BadgeOS plugin that allowed us to build a badge program directly on a WordPress site. The QSLiN website already uses WordPress so this was a natural fit. We did look at other options, but felt that our comfort with WordPress would allow us to develop the site and program quicker, reducing labour hours, and create a better quality product. In the end, instead of creating a completely independent site, the badge program was incorporated into the QSLiN website (http://qslin.org/digitalbadging/). WordPress also allows for community interaction-participants are allowed to share their accomplishments on the site as well as via social media. As well, when participants submit for higher-level badges (silver and gold), they can do so publicly (e.g. Linkedln, Facebook etc.) and allow for comments, feedback and discussions to follow. By using their own free Credly account, participants can also share and demonstrate their skills to a larger global audience along with any other badge they have achieved using the Credly badge platform.

\section{Framework}

A framework for the badges was drawn up and revisited numerous times to ensure that the structure continued to make sense and did not appear too unwieldy. As well, the 
content for each badge was scrutinized to look for overlap and repetitiveness. It was also important to continuously verify that the content met the goal of educating library staff to understand what a library learning commons is and what they could do in order to improve their school libraries. While developing the badges, there were many questions that had to be asked, such as the following:

How does one earn the badges (what activity, quiz, submission)? Is the badge to be automatically awarded or does it have to go to a moderator who then credits the participant? If so, who will issue the badges?

It was decided that bronze level badges would remain consistent in the number of steps required to achieve the badge, for example, each sub badge is no more than three steps, and most are two. All bronze level badges require completing a quiz successfully. Silver badges require a plan of action created by the participant. In order to achieve the relevant gold badge they will then have to demonstrate how their plan was put into action. The silver and gold level badges require validation by a member of our team. This could be changed over time to include additional badge validators/issuers once participants have gained a certain number of badges. The badge program team continues to make regular efforts to ensure that the content is kept up to date and is still

online (as many resources are YouTube films, websites, etc. which may be removed or edited by their creators).

\section{What information do we need from participants and how can we assure their privacy?}

It was important to us that we protect participants' privacy as much as possible. The only information that we require from participants is an email address. They can choose a username and password that keeps them as anonymous as they wish to be. The participant can also choose how much of their achievements they choose to share with the public, from nothing to every achievement along the way. Additionally, our web hosting company is Canadian with servers in Montreal. This was an added important security and privacy feature that we welcomed.

\section{When a badge requires more than just a quiz or online activity, how will participants submit?}

For the silver and gold level badges, a more complex submission is required. For a silver badge, typically a "plan of action" is required, so it was decided that Google forms would be an easy way to build a document that participants can save and print for themselves while also being submitted to the badge site. For gold level badges, where participants need to submit a document, video or other such media file, we encourage them to upload their content to a "cloud type" platform and share the link in their submission (for example, upload their videos to YouTube or their PowerPoint presentations to SlideShare, or to link them to a blog post). We, the developers of the program, assess the submissions and award the badges. In the future, as participants 
become experts on the standards by achieving a number of gold badges, it is possible that they will become badge issuers for their school board or community.

\section{As the site grows, how will we deal with traffic and storage issues? How will we manage the program and remain up to date?}

We spent a lot of time researching the platform as well potential web hosting options. Using WordPress, a stable platform, as well as plugins that offered good customer service and met our needs was a priority. The web hosting company is flexible and friendly with many options to upgrade in terms of speed and space as needed for very reasonable prices.

\section{Badge Framework}

It was decided that each of the five CLA standards would be broken down into their categories. Within each category a participant has the opportunity to achieve a bronze, silver, and gold level badge. Where possible, badge categories were merged in order to simplify the process from both the developer's and the participant's perspective. We wanted each level to emulate the notions presented in the Leading Learning guide that reflect the stages of evolving a traditional library into a Library Learning Commons: exploration, emerging, evolving, established and leading. See Table 1 for an outline of the levels, the materials used to illustrate concepts as well as how the levels were assessed. See Figures 2 and 3 for the mock-ups and images for the framework.

Table 1. Explanation of badge levels

\begin{tabular}{|l|l|l|l|}
\hline Badge Level & Concept Level & Materials & Assessment \\
\hline Bronze & $\begin{array}{l}\text { Exploratory, } \\
\text { familiarize with } \\
\text { importance concepts }\end{array}$ & $\begin{array}{l}\text { Videos, Prezis, } \\
\text { articles, Google } \\
\text { forms }\end{array}$ & Quiz \\
\hline Silver & $\begin{array}{l}\text { Application of skills } \\
\text { expected }\end{array}$ & $\begin{array}{l}\text { Videos, Prezis, } \\
\text { articles, Google } \\
\text { forms }\end{array}$ & $\begin{array}{l}\text { Plan of action } \\
\text { created with a } \\
\text { Google form }\end{array}$ \\
\hline Gold & $\begin{array}{l}\text { Evidence of } \\
\text { application of } \\
\text { knowledge in } \\
\text { professional life }\end{array}$ & $\begin{array}{l}\text { No new content } \\
\text { introduced just } \\
\text { criteria }\end{array}$ & $\begin{array}{l}\text { Participant's } \\
\text { choice of } \\
\text { submission but } \\
\text { must be based } \\
\text { on their plan of } \\
\text { action (for } \\
\text { example, link to } \\
\text { a video, } \\
\text { presentation, } \\
\text { images, } \\
\text { document, etc. })\end{array}$ \\
\hline
\end{tabular}




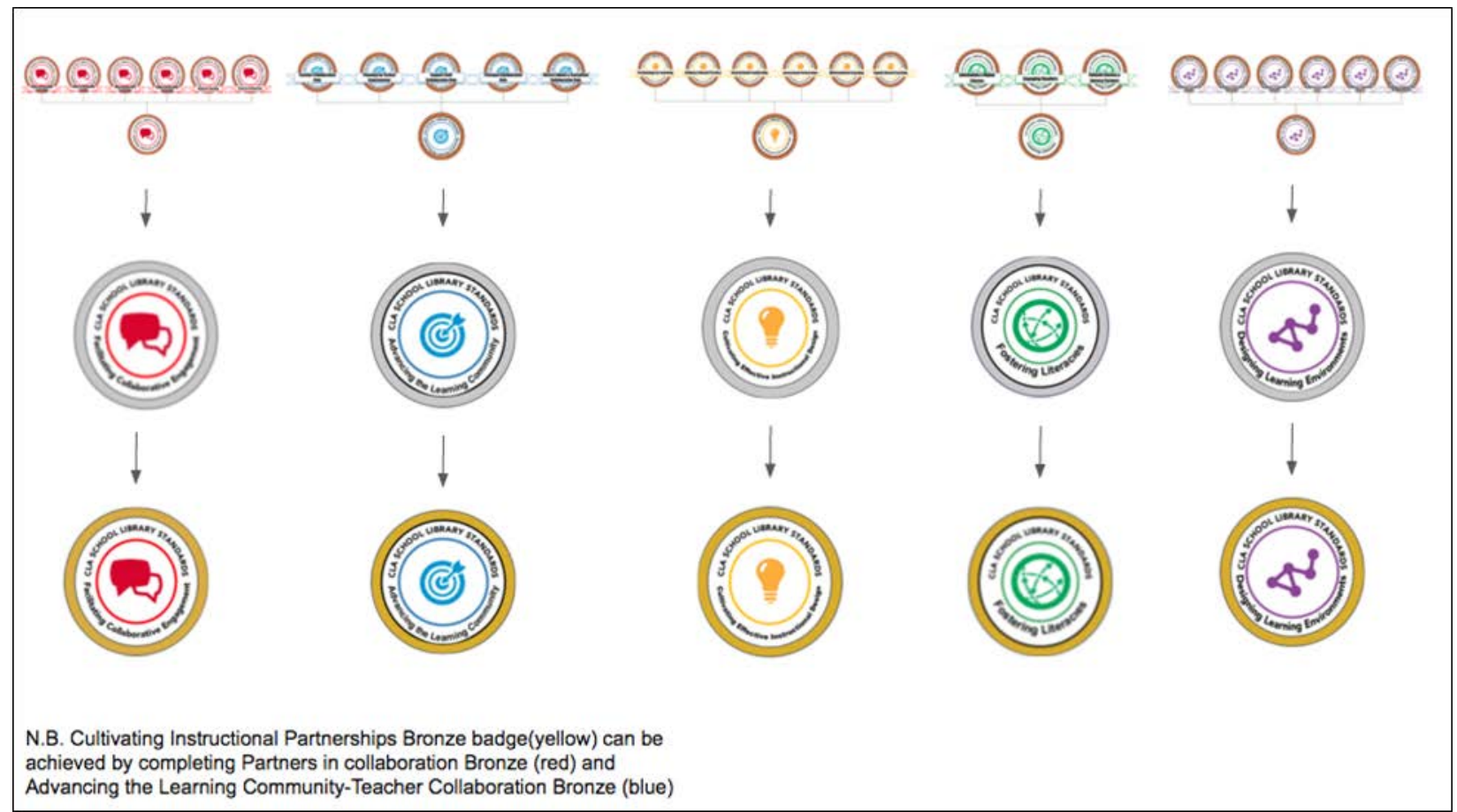

Figure 2. CLA Standards Badge Constellation (QSLiN, 2015). Badge logos used with permission from the Canadian Library Association.

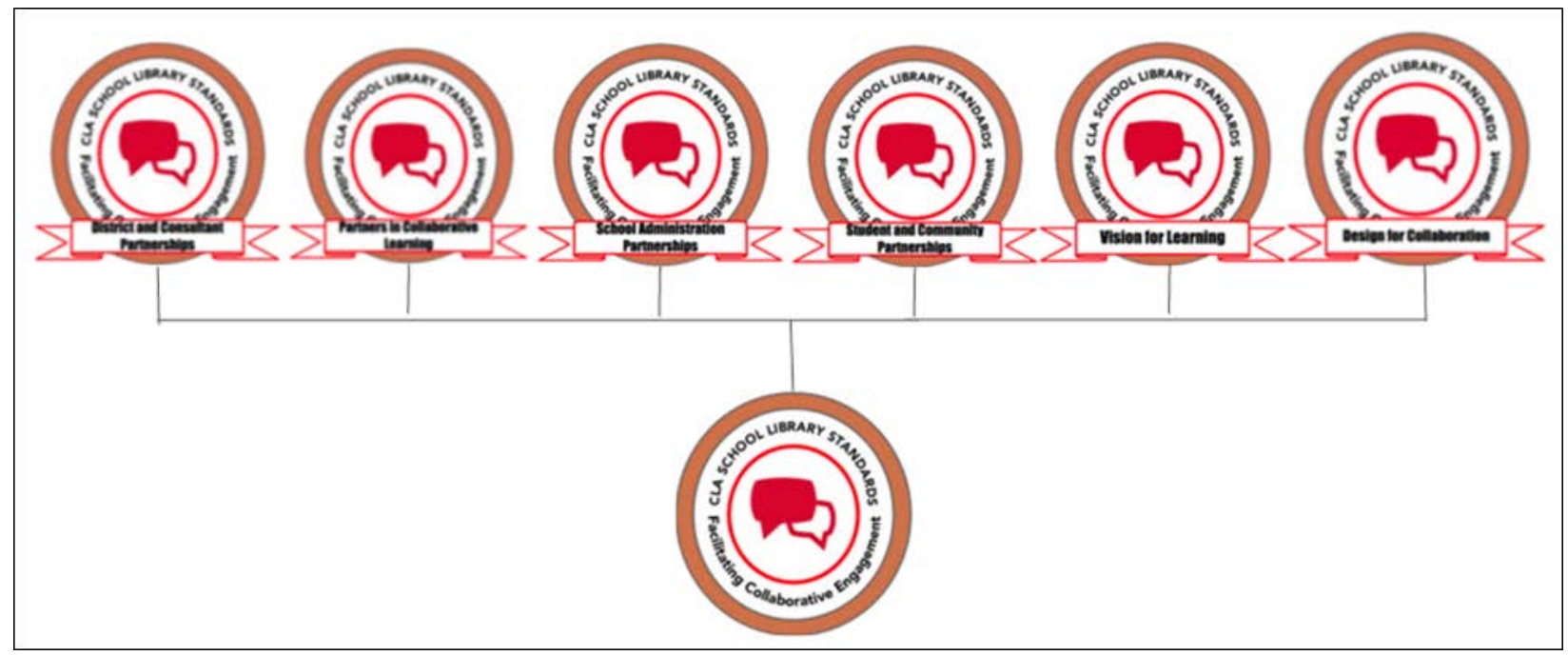

Figure 3. Facilitating Collaborative Engagement (Red) Badge Map (QSLiN, 2015)

\section{Validation}

Once the badges and content were created, gathered, edited, arranged and uploaded, the beta-site was presented to the QSLiN committee for validation. Members went through the process of earning badges and provided feedback on their experience. This feedback was then used to tweak the site. As participants begin to use the site, we will regularly seek and welcome feedback to help create and improve a product that truly meets the needs of the Quebec and Canadian school library community. The digital 
badge professional development program was officially launched at the Congrès des milieux des documentaires, a Montreal-based library super conference for all Quebec library associations, which was held on November 19th, 2015. For a quick tour of the badge site, please look at this video.

\section{Future Considerations}

As we continue to make improvements to both the content and design of the badge program, we have also discussed possible next steps.

Similar to online webinars or in-person workshops that provide certificates, we would like to petition various library associations and educational institutions (for example ABQLA's School Section, APSDS, and McGill University Information Studies Department) to provide a "seal of approval" in order to add greater credence and acknowledgement to the badge program. We feel that this will add greater value to the work and efforts made by participants and encourage participants to engage in a worthwhile initiative.

As we continue to analyze user statistics and feedback, we regularly discuss ways that the program might be improved and added to. For the second phase of this pilot project, we would like to add new related badges that users can earn for deeper exploration and sharing of the various elements within the Library Learning Commons. These can be Quebec-specific badges (each Canadian province having their own education program), or it may be a technology-specific badge that would benefit the library.

We would also like to see greater interprovincial collaboration between associations or school libraries whether on an individual or board/district basis. As each province has unique needs and circumstances, we would like to work with other provinces to help develop badges that meet their specific needs as well. We would like to see this program used nation-wide as we continue to advocate for school libraries and persevere in bringing school libraries to the forefront of education. For now, we have primarily focused on sharing the badge program via social media and our blog.

While the badge program does not replace the original CLA publication, it does complement its ability to help guide school libraries forward. With the dissolution of CLA, we hope that a Canadian association of school libraries or other such national initiative arises in order that the Leading Learning publication remains up to date. If not, the QSLiN group will have to address how we will keep our badging program current and relevant. Our hope is that this badging program provides an accessible and dynamic way to educate librarians and contributes towards the future of librarianship in the educational community. 


\section{References}

Alliance for Excellent Education and the Mozilla Foundation (August 2013). Expanding education and workforce opportunities through digital badges.

Barack, L. (March 6, 2012). Full-time school librarians linked to higher student reading scores. School Library Journal.

Bellardo-Hahn, T. \& Lester, J. (2012). Faculty needs and preferences for professional development. Journal of Education for Library and Information Science, 53(2), 82-97.

Canadian Library Association. (2014). Leading learning: Standards of practice for school library learning commons in Canada.

Cox, M. (2015). Back to the future professional development. Knowledge Quest, 43(4), 46-53

Fields, E. (2015). Making visible new learning: Professional development with open digital badge pathways. Partnership: The Canadian Journal of Library and Information Practice and Research, 10(1).

Haycock, K. (2011). Connecting British Columbia (Canada) school libraries and student achievement: A comparison of higher and lower performing schools with similar overall funding. School Libraries Worldwide, 17(1), 37-50.

Jovanovic, J. \& Devedzic, V. (2014). Open badges: Novel means to motivate, scaffold and motivate learning. Tech Know Learn, 20 (1) 115-122.

Lance, K., \& Hofschire, L. (2012). Change in school librarian staffing linked with change in CSAP reading performance, 2005 to 2011. Denver, CO: Colorado State Library, Library Research Service.

Oberg, D. (2012). Ignoring the evidence: Another decade of decline for school libraries. Canadian Education, 52(2), 31-34.

Peer 2 Peer University, The Mozilla Foundation in collaboration with the MacArthur Foundation. (2011). An open badge system framework: A foundational piece on assessment and badges for open, informal and social learning environments.

Schrage, M. (Dec. 28, 2012). Four innovation trends to watch in 2013. Harvard Business Review www.hbr.org 